\title{
Rivers revitalisation: approaches to decision
}

\author{
Tetiana Alokhina* \\ Center for Problems of Marine Geology, Geoecology and Sedimentary Ore Formation National Academy of Sciences of Ukraine, Section \\ of geology and environmental problems of ore deposits, Kyiv, 01601, Ukraine
}

\begin{abstract}
The article is focused on the successful implementation of the global goals of restoring water objects in the context of sustainable development that is impossible without solving the regional problems of local watercourses and reservoirs reviving. It is emphasized that awareness of riparian spaces role as ecological corridors and importance of the healthy functioning of the river network through the revitalisation of even minor watercourses leads to growth attention to this problem in an increasing number of countries. On the example of the Slepiotka River in Katowice and Inhulets River in Kryvyi Rih the aspects, on which attention of revitalisation are accented in European countries and in Ukraine, are presented. In European countries, the basis for the approach to river revitalisation is their functioning as integral ecosystems. In Ukraine, nowadays, the main focus of river restoration is on cleaning them from silt sediment. In this article the approaches to decision of river revitalisation questions are presented. The main of them are: enhancing the ecological functionality of the watercourse as an ecosystem; providing flood protection; increasing the residential, cultural and recreational value; securing permanently sustainable use of watercourses and their river valleys.
\end{abstract}

\section{Introduction}

Nowadays science provides a better understanding of the extent to which our shared progress as human beings is undermined by the ways in which we have gone about achieving it, and too recognizes the Earth as a closely linked human-environment system. Science and technology in the modern time are powerful agents of change, depending on how and where they are headed. Increased science-policy-society cooperation can use achievement in our understanding of coupled humanenvironment systems and the shaping of innovative pathways towards achieving the Sustainable Development Goals. The fact that a large number of countries are now incorporating science, technology and innovation in their national development agenda is a promising sign [1].

Governments can lead the transformation of the world's social, economic and environmental status towards universally beneficial outcomes when guided by the Sustainable Development Goals. But they must recognize that such transformation will involve tough choices and trade-offs. There is a growing tendency for governments and companies to invest in sustainable technologies. Over the past 10 years, at least 101 economies across the developed and developing world (accounting for more than 90 per cent of global GDP) adopted formal industrial development strategies, which increased opportunities for formulating new ways to promote innovations toward sustainable development.
However, developing technology alone is not enough: technology must be made accessible and sufficiently attractive to encourage widespread adoption. Hence, in addition to research and development, the scaling up and the adoption of sustainable technologies are critically needed [1].

Understanding of an interconnection all the water resources of the Earth requires solving an issues of preservation and revival of not only the oceans and seas, but also a river network as a whole [2].

The situation of river spaces, especially of urban river spaces, in the European countries and in Ukraine, in the end of XX century, was in one sense very similar. In the context of industrialisation processes that occurred from the end of the 19th century through the first half of the 20th century, rivers and streams were used for sewage discharge, regulated and straightened for land reclamation and agricultural use, paved, channelled for flood protection (technical solutions) or even culverted. Areas by the riverside were often used commercially. Industrial zones and technical infrastructure such as roads or railway tracks were built in the floodplains. Large rivers were extended and used as waterways. During the second half of the 20th century riverside areas were subject to structural changes - industrial zones were partly abandoned, resulting in brownfields and deteriorated open spaces. Thus, up to the present day, urban river spaces suffer from lack of ecological functions (such as lack of habitat and biotope network function, lack of passability, contamination), lack of social functions (lack of accessibility of watercourses, lack of attractive open

\footnotetext{
* Corresponding author: Alohkina@gmail.com
} 
spaces next with water, inadequate perception of rivers by the public) and other problems.

With increasing awareness of role of riparian spaces as ecological corridors and areas for social activities, active protection and restoration of such areas has been recognized as a fundamental element of measures implemented to shape the special order and sustainable development of cities. Since the 1980s, awareness of ecological issue has risen, although at different speeds in western and eastern European countries. In the western countries revitalisation and renaturation rivers began in the 1980s whereas in the central European countries it did not commence until after 1990s.

In West Germany, since1980s an increasing number of river management projects have been developed and realised based on the insight that attention to ecological aspects of river maintenance does not hinder but can indeed play a role in improving flood protection $[3,4]$. In the Eastern European countries Poland and Czech Republic, these processes did not begin until after the fall of the Iron Curtain. As for such countries as Ukraine - this practice is only beginning to appear $[5,6,7]$. Also, the potential recreational function of rivers is differently appreciating in the West and East.

In densely populated and industrialised areas, revitalisation of urban river areas contributes to a high quality of the environment as well as to a high quality of life. Urban river spaces are often the only functioning or potential reservoirs of biodiversity and open spaces in cities. Thus, the active protection and restoration of such areas is part of the repertoire of fundamental practices for shaping cities' spatial order and sustainable development.

The aim of our work was a comparative analysis of approaches to river revitalization, which are used in the European Union countries and in Ukraine. As examples, the Slepiotka River in the Polish city of Katowice and the Inhulets River in the Ukrainian city of Kryvyi Rih were selected.

River revitalisation is not just about rivers. The preparation and implementation of a revitalization project is not limited to technical questions of hydraulic engineering but touches all aspects of sustainability.

Issues related to the restoration of river ecosystems can be considered from different angles. In our country, the revitalization is most often understood as a process of bottom dredging, which is necessary either for shipping purposes or in the context of the removal of contaminated sediments. Whereas in European practice much more attention is paid to restoring the hydrodynamics of the watercourse, the formation of characteristic ecotopes, as well as the recreational component.

The concept of revitalization was formulated by V. K. Khilchevsky [5, 6]: "This is the complete restoration of watercourses or certain sections thereof at the level of the river's existence, which preceded the industrial development of this region; when the river network was undisturbed and no centralized or point sewage discharges were made".

The issues of rivers revitalization in Ukraine at the state level are not yet considered comprehensively. The focus is on aspects such as dredging to improve shipping or the comprehensive programs for the elimination of consequences of flooding in the cities and towns of Ukraine. The latter is the Cabinet of Ministers of Ukraine resolution of 15.02.2002 No. 160 .

In last years the processes of the bottom purification and dredging are activated in different regions of Ukraine. Cases of fragmentary manifestation of elements of modern river revitalisation are beginning to emerge at the level of urban communities. So, in Lutsk, elements of revitalization of the Saralaevka River - the right tributary of the Styr River was accomplished in 2013-2014 years [7]. The work was carried out on a small plot of $0,5 \mathrm{~km}$ in the central part of the city jointly by the city authorities and business structures. A revitalisation project consists of many different tasks and requires the cooperation of many different experts and also laypeople, who are convinced of the project's success.

\section{Objects and actions}

Current planning methods in the European countries and in Ukraine have an impact on the implementation, realisation and acceptance of urban river revitalisation projects. Legal and technical regulations, generally available information and information provided by local, regional and state authorities as well as the development of planning criteria, the "planning philosophy" and the self-understanding of landscape architects and town planners all affect the outcomes of urban river revitalisation projects.

Below, the certain aspects and approaches to the revitalization of the Slepiotka River in Katowice and the Inhulets River in Kryvyi Rih are presented. We will consider the main points on which attention was focused in the projects, of which the author was a participant.

It is well known that the basis of large rivers water balance is a flow of small rivers. Small rivers hydrology, hydrochemistry, water quality is closely related to local geological-geomorphological, soil-plant conditions and anthropogenic processes that occur at a specific catchment. The formation of small rivers and their basins is determined by the surface runoff from regional landscape complexes, therefore an effect of natural and anthropogenic factors on such sites manifests faster and more clearly. It makes ecosystems of small rivers more vulnerable both a result of the direct impact on them of pollutants and indirect influence.

Transformation of Slepiotka River in Katowice. Katowice is a city in southern Poland, where in mid- $18^{\text {th }}$ century was discovered rich coal reserves. In the first half of the $19^{\text {th }}$ century intensive industrialization transformed local workshops into industrial steelworks, mines, foundries. Now Katowice is a large coal and steel centre. For decades if not a century, in this region, rivers and streams were regulated and straightened for land reclamation and industrial use. They were paved or even tubed. For a long time, streams of all scales were adopted to discharge excess water and sewage. The regulation and channelisation of river beds, construction of drainage works and the implementation of active flood protection contributed to degradation of the river valleys. 
The main goal of the revitalization action in Katowice was to recreate a blue-green river valley corridor in the highly urbanized, mid-part of Slepiotka River [8]. This particular stretch of the river was chosen for special, ecological and social reasons. The local catchment features numerous forms of land use and an advantageous land-owners structure, since most of the riparian area was municipal property. This river has quite suffered from the discharge of untreated sanitary sewage, but the flood risk was insignificant (figure 1). Additionally, it was located in the neighbourhood of a large housing estate in the direct Ochojec in the centre of Katowice. Access to the river and recreational facilities would improve the living conditions for thousands of inhabitants in the adjacent area. Thus, public support for the idea of revitalisation was high.

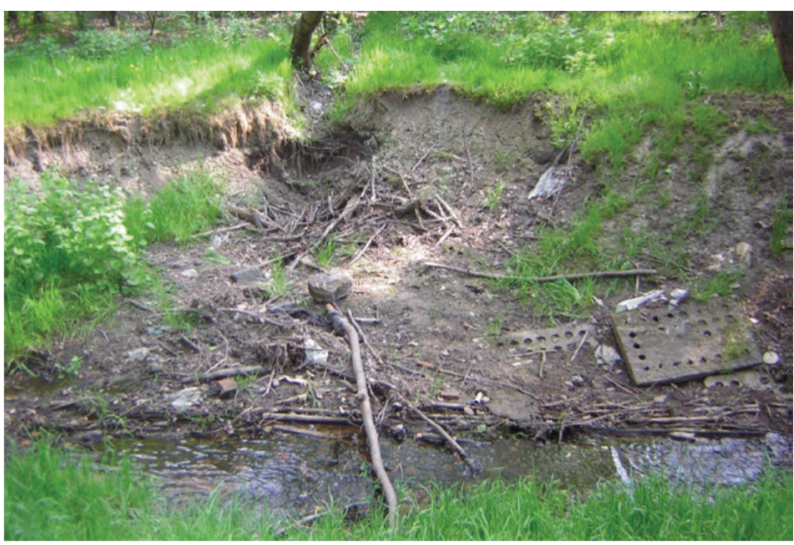

Fig. 1. Slepiotka River before transformation [8].

The authorities of Katowice city wanted to integrate the concept of a river corridor into special planning and management practices in post-mining urbanized areas, to re-establish a green axis along the river valley and to enlarge the public open leisure space. Furthermore, seminatural wetland was to be created in order to increase the retention capacity and amphibious as well as water habitats and to establish a new paradigm for urban water management.

The revitalisation project on the Slepiotka River in Katowice is the opportunity to illustrate ways to implement the proposed transformation of the complete corridor of Slepiotka River. Not only did they want to increase the habitat diversity, establish a stable plant cover by using native plant species, and re-establish riparian forest, dry forest and wetlands habitat. They also aimed to show applications of soil bioengineering methods in order to establish buffer-zones that would protect the river from contaminations (figure 2).

The project included, among other things, the reconstruction of $210 \mathrm{~m}^{2}$ of the dry old river bed and $950 \mathrm{~m}^{2}$ of the wet old river bed, formation of a sand dune, construction of wooden bridges across the river and the old river bed, and setting-up of information boards.

The Slepiotka River action achieved several goals: The planned revitalisation was successfully implemented and the pilot action served as a very good starting point for preparation of the valley development plan. Most of the expectations of the City of Katowice and the researchers at the Central Mining Institute concerning revitalisation effects, development of habitat diversity and land use transformation were fulfilled. Moreover, the river corridor concept developed and tested in the pilot action area proved to be suitable for implementation along other parts of Slepiotka River and even at sites along other rivers.

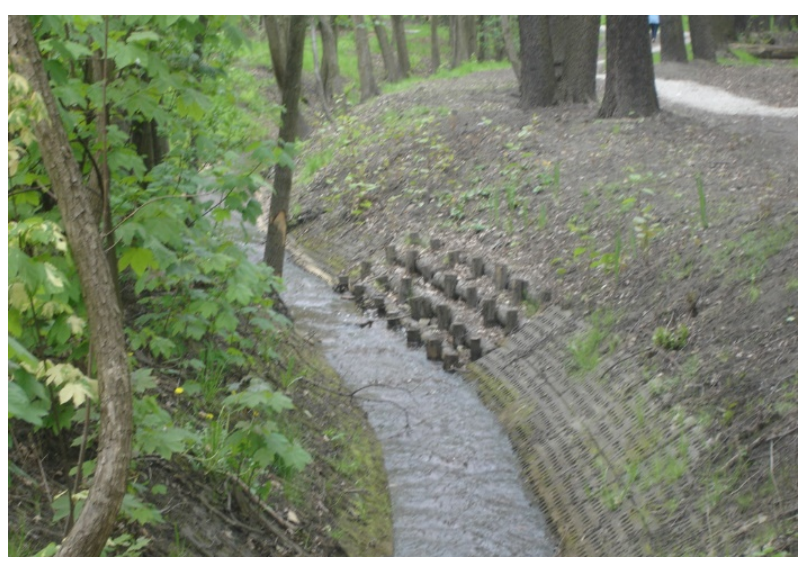

Fig. 2. Slepiotka River after transformation [8].

Public involvement proved to be one of the most important aspects of the Slepiotka River revitalisation that had not been discussed previously. The City of Katowice as the coordinator of public participation and cooperation managed to involve numerous actors.

Besides city representatives, administrative partners included managers of the Slepiotka Valley, educational institutions as well as maintenance and safety services. Several universities and research institutes also participated in the partnership. Furthermore, the local community and private land owners from Slepiotka valley, NGOs, architects, artists, historians, and the media, among others, participated in workshops and meetings on the development of a long-term vision for the Slepiotka valley.

The workshops proved the potential of institutional, public, private and research-based cooperation and resulted in models of cooperation for the river valley partnership that increased the problem-solving competences by combining interests and ensuring the convergence of goals. Thus, public participation procedures helped to develop a coherent vision of spatial management for Slepiotka valley and led to overall satisfaction in the local community.

Riverbed purification in the Inhulets River in Kryvyi Rih. Kryvyi Rih is the largest iron ore mining and processing centre in Ukraine. The territory, where from narrow meridional strip 1,0-3,0 km wide and 100-150 km long, has mined 2,2-2,8 billion tonnes of chemically pure iron over the last 125 years [9]. Undoubtedly, long-term and large-scale man-made activity in this region has reflected on all components of the biosphere: lithosphere, atmosphere, hydrosphere. Technogenic origin products are constantly occur in compound of rivers sediment which flowing though this territory: particles of metallurgical slag, sludge, tailings of ore-dressing and other wastes. And the rivers look more like sewage gutter.

The accumulation of environmental problems and the consequent increase in community dissatisfaction has 
prompted city authorities to seek solutions to the situation. At the same time, community awareness of the role of river valley as a network of environmental corridors and places of social activity was increased.

In 2014, the Dnipropetrovsk Regional Water Resources Administration entered an agreement with the private enterprise "Universalgasbud" for the implementation of the project "Anti-flood measures and improvement of the hydrological status of the Inhulets River in Dnipropetrovsk region".

The main purpose of the planned activities was implementation the Cabinet of Ministers of Ukraine resolution from 15.02.2002 No 160 "The comprehensive program for the elimination of consequences of flooding in the cities and towns of Ukraine". And also an implementation the regional program "The elimination of the effects of flooding the territory in cities and towns of Dnipropetrovsk region for the period till 2030" which was approved by the decision of the regional council of July 18, 2003 No 184-9/XXIV.

Among other works, significant of works were planned to clean up the Inhulets River in different parts of the Kryvyi Rih city. A project was planned to clear up $4,3 \mathrm{~km}$ of the riverbed and $0,5 \mathrm{~km}$ an old tributary of the Inhulets - the Saksahan River. Elements for a revitalization of the Inhulets River section and it tributary of Saksahan River, in the central part of the city in the park area, were implemented. The works included the riverbed purification, clearing the banks, arranging the territory (figures 3, 4). Sediment, removed from the river, was mainly deposited at landfills. The works which carried out in the city centre contained elements of revitalization, but the main goal was not done - to restore the flow of the river. The cleared areas are little flowing part of the riverbed.

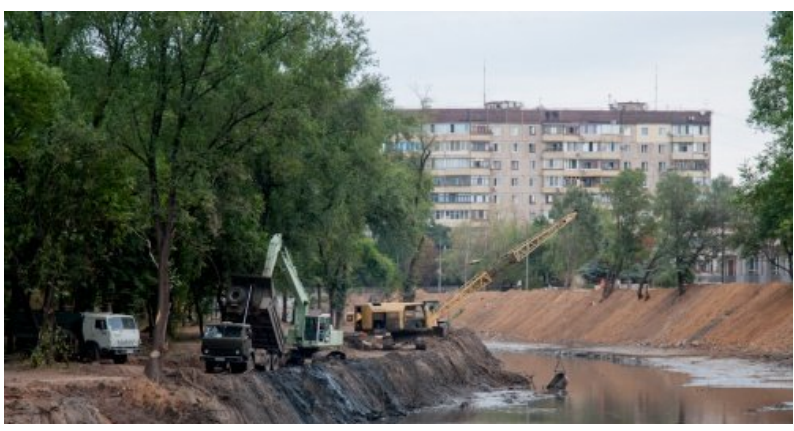

Fig. 3. Works for purification of the Saksahan River [10].

The main goal of the second stage of works the riverbed purification in the Inhulets River (in 2017) was the removal of a large amount of contaminated sediment. Contaminated sediment was formed as a result of activity the ore-dressing factories and the metallurgical plant, which are located higher on the river flow. The initiative to carry out these works came from community of a nearby area.

During dredging and purification operations, a significant amount of subaquatic polluted and man-made transformed sediment was raised to the surface. A method of carrying out the cleaning operations included lifting of bottom silt in a semi-liquid state with the help of a dredge and burying it in ditches, which were located on the low bank of the river at a distance of 10-20 m from the river bank (figures 5,6 ). The issues of storage and/or burial of the raised sediment are relevant and important, because it contains significant concentration of heavy metals, radionuclides and other pollutants.

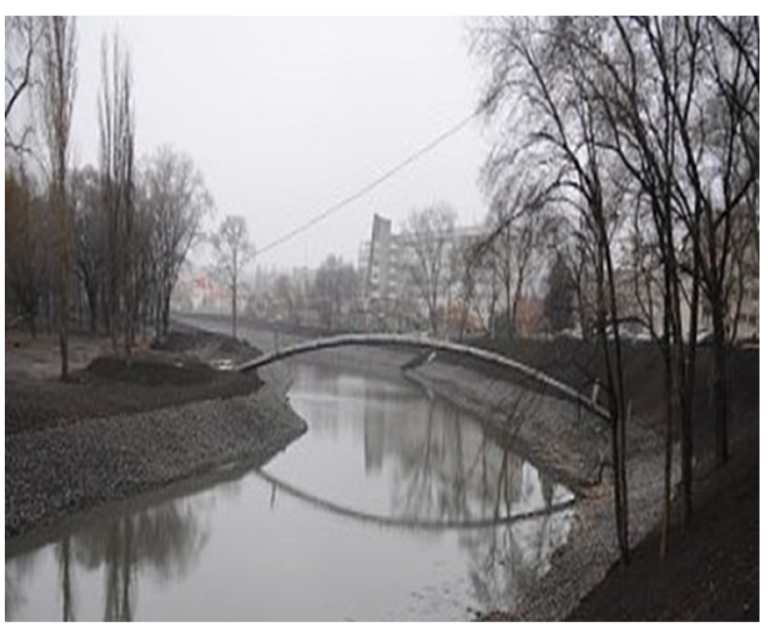

Fig. 4. The intermediate stage of revitalisation project on the Saksahan River [10].

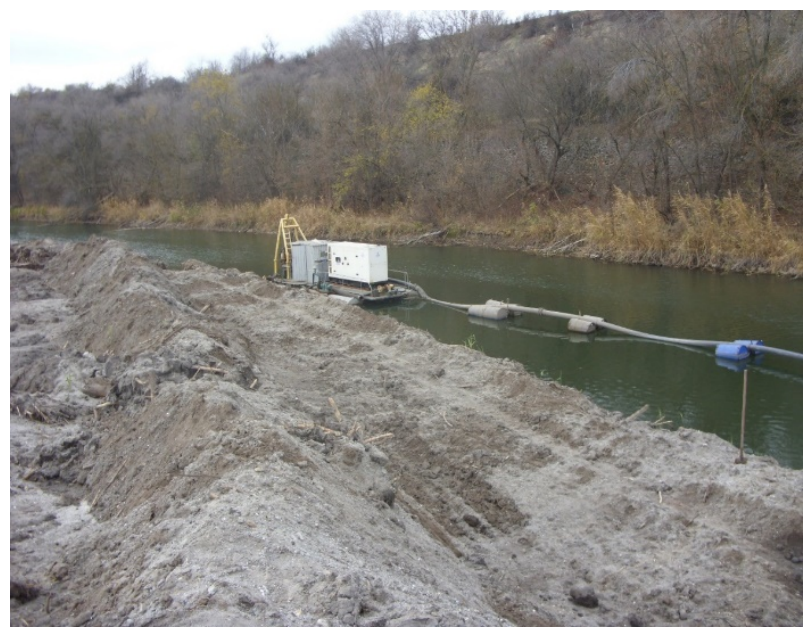

Fig. 5. Inhulets River. Stage of bottom purification (author' photo).

As you can see from the photo (figure 6), the ditches bottoms did not have any waterproofing, so in a short time a variety of pollutants (including heavy metals) can return end up in the river again. Also, there is a constant washing away of the upper soil layer, because after the backfilling of the ditches, phyto-recultivation works were not implemented.

\section{Analysis and discussion}

Thus, the features of the implementation of river revitalisation works of the Slepiotka River in Katowice and the Inhulets River in Kryvyi Rih were presented.

Environmental aspects and nature conservation have only gradually become incorporated into legal and regional programs; as a consequence, this contributes to reducing water pollution and tackling river revitalisation. 


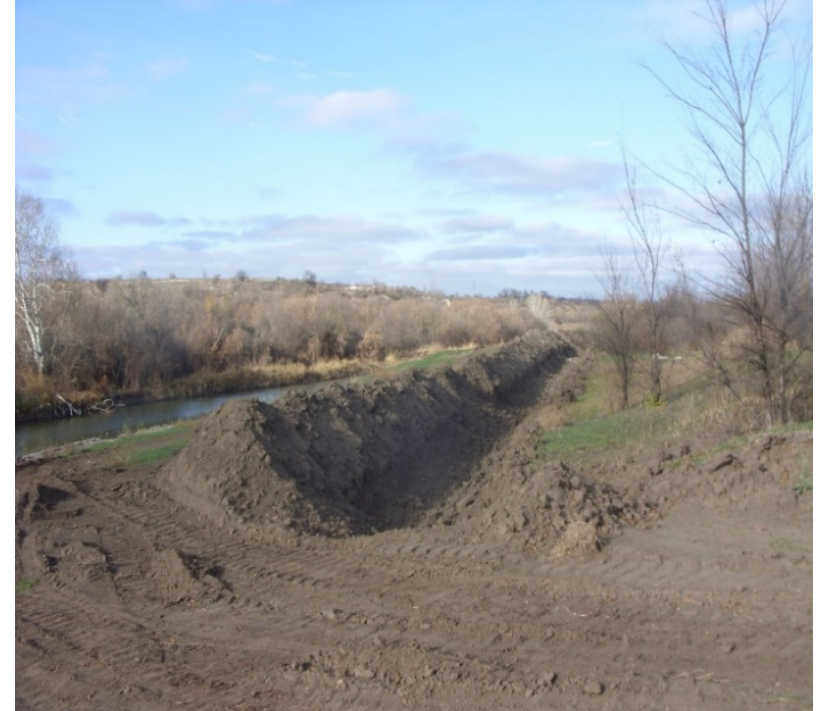

Fig. 6. Inhulets River. Ditch along the river which intended for burial of sediments (author' photo).

The main tasks of the revitalisation in European countries, and in Poland in particular, are questions of flow restoration, improved hydrodynamics, selfpurification and ecosystems restoration. In the same time, the main goal of the revitalisation in Ukraine are still the issues of purification the riverbed from silt or questions relevant to preventing flooding. And on large rivers, the main problem of cleaning operations is the restoration of navigation. In rare cases, the purpose of revitalisation is to increase the recreational attractiveness of the territory (most often we are talking about the central areas of cities).

Waterfront areas, were often used commercially, start to using more and more as recreational zones. However, industrial zones and technical infrastructure such as roads or railways tracks, factories are staying in the floodplains. Even after industrial utilisation of inner-city began to decline, riparian post-industrial areas are still left abandoned. The visual and functional attractiveness of rives as well as the perceptibility of water courses are low. Public access to the river continues to be of little importance as are its ecological functions.

Here we will try to lay out main aspects of successful river revitalisation. One of the main aims of revitalisation addresses the enhancement of the ecological functionality of the watercourse. Secondly, river revitalisation is a means to implement flood protection. Onwards, it contributes to increasing the residential, cultural and recreational value of the area, and finally, it helps to secure the permanently sustainable use of watercourses and their flood plains.

From the experience such countries as Poland, Czech Republic and Germany [3, 4, 8, 11-14] and the own experience a participation in a some revitalisation projects $[8,9,15]$ have been developed the following approaches for urban river revitalization. The approaches are intended to help planners, decision-makers, executing authorities and stakeholders consider the wide range of aspects (ecological, economic and social) relevant to the specific requirements of river revitalisation in an urban environment. The approaches are divided into four basic groups which are shown on the scheme (figure 7). Each of these four basic components consist of a range of issues.

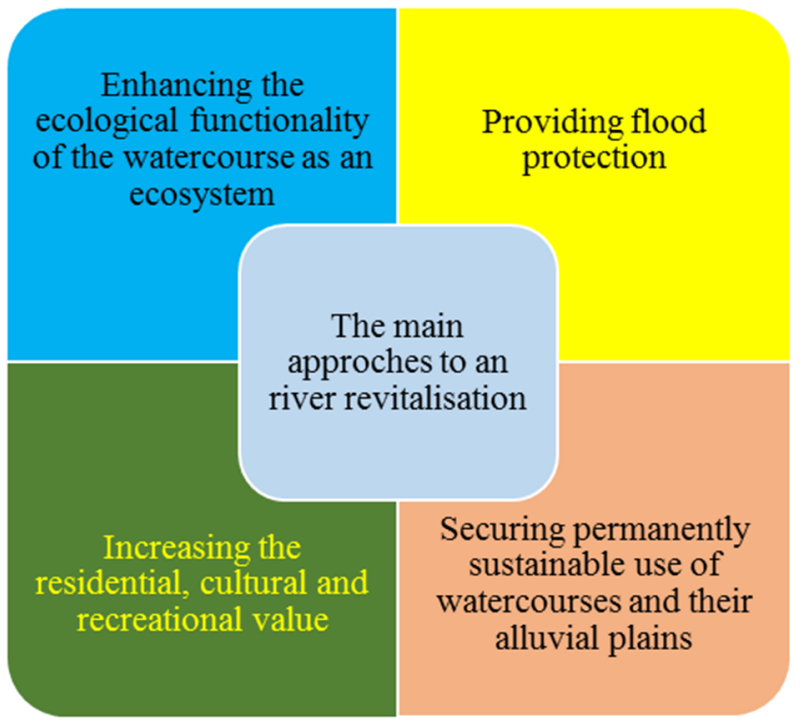

Fig. 7. The scheme of an approaches to a river revitalisation.

Enhancing the ecological functionality of the watercourse as an ecosystem can include next aspects:

- Renewal the hydrodynamic regime of watercourses. It can be achieved by increase the morphological diversity of the riverbed as well as the discharge diversity and its dynamics; by modify of the sediment regime through a suitable longitudinal profile of the watercourse.

- $\quad$ Renewal minor watercourses can be done by to remove the channeled underground stretches of the watercourses and prevent further channeling; by deepening a shallow section of riverbeds; if possible, by re-meander straightened river beds in minor watercourses, according to their historical development.

- Improve the water quality can by support the self-cleaning capacity of watercourses; by addition water infrastructure (build separated sewer systems, wastewater treatment plants); by pre-treat rainwater before it reaches the river. One of the main solutions - to eliminate pollution sources.

- Increase the biodiversity of the biotopes in river valley can achieved by improve local habitats according to the local conditions of each river valley; by remove invasive plant species; by support the reintroduction of native plant species and habitats.

- Assurance migration permeability of watercourses can be achieved by build fish passes; by provide migration permeability by transversal objects (stepped weirs and chutes), and technical alterations (shallow water column and high flow speed) to the watercourse.

- Need to give an advantage nature-like adaptations over technical modifications to the landscape.

Providing flood protection can include next aspects:

- Mitigation the risk of flood damage with help: adopting the idea that rivers need more space; need to 
avoid artificial elevation of terrain due to building development in active flood zones.

- Increase the retention capacity of the landscape can be achieved by allow the natural overflow of rivers into the alluvial plains; need to renew and create wetlands, where it is possible; to implement elements of the systems of ecological stability.

- Reducing direct outflow from the drainage area (especially important for small watercourses) by the increase the rate of rainwater infiltration in the area by allow its infiltration into the soil profile; reuse excessive rainwater in households and the municipal sector.

- Implementation technical measures to catch extreme flow rates: use retention tanks and dry polders in the river valley.

Increasing the residential, cultural and recreational value may be consist of next elements:

- Incorporate water into the city's image as a major landscaping feature of the urbanised space. So, we can use the alluvial plains as significant urban spaces with a unique potential for recreation and leisure.

- Access to the water as a security and pleased moment to leisure: building play facilities providing interaction with the water element; provide possibilities for fishing; allow direct public access to the watercourse in some places where it is safe and possible.

- Creation sport and recreational paths (greenways) along watercourses. Creation or combination paths for pedestrians, cyclists, in-line skaters and other non-motorised users, following the terrain in the alluvial plains. Improve a connection of the city with the surrounding landscape

- Building sport and recreational facilities in the alluvial plains. Creation places for short-term recreation of the public along the sport and recreational paths.

- Ability to provide supplementary infrastructure. Building an information system along the sport and recreational paths (signposts, information boards, panels along educational paths providing information about natural and cultural features and values in the area). Installation street furniture; presentation artefacts and temporary exhibitions.

Securing permanently sustainable use of watercourses and their river valleys can be achieved:

- By improving the applicability of the land use planning process in terms of flood control and watercourse protection. Need to use the instrument of land use planning to apply the above-mentioned principles in the revitalisation of watercourses in urbanized areas. Need to develop more detailed rules for the use of built-up areas concerning the risk of potential.

- Set rules for water withdrawal to secure a sufficient flow volume for maintaining the dynamic water regime of watercourses.

- Minimise conflicts with infrastructure (bridges, roads, pipelines).

Main steps of successful river revitalisation include: planning (with all stakeholders' involvement), implementation, scientific and educational compound, public relations activities and financing.
Planning. It is very important to consider the aims and requirements of sectoral planning (especially plans and regulations of the water management authorities, nature conservation management authorities and land use management authorities) and of spatial planning and include the revitalisation project in these aims. So need to have the revitalisation project incorporated into the relevant region and local spatial management plan, especially if the project is not limited to a single site but will affect the whole course of a river or a creek within the city or urban spaces with adjacent river banks and flood plains. In this way the project will be protected authorities and will have to be taken into account in subordinate planning. Additionally, an environmental impact assessment might be required. On the figure 8 a planning model of the river revitalisation is introduced.

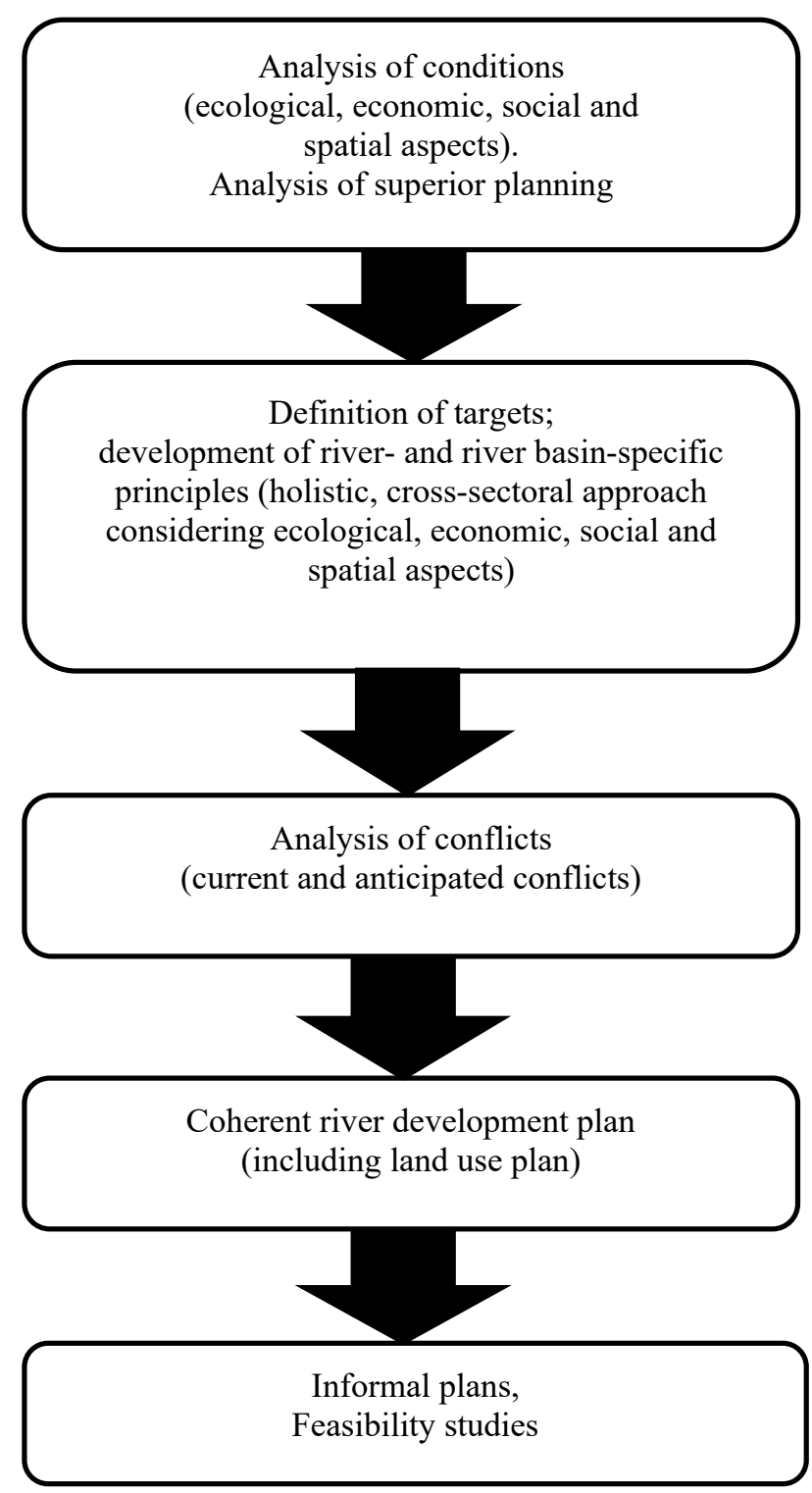

Fig. 8. Scheme of planning the river revitalisation activities.

Furthermore, improving the availability, visibility, attractiveness and safety of riverside areas has to be incorporated into the revitalisation project; secure access to the water and continuity of waterside routes should also be ensured. Waterfronts are socially as well as 
economically important determinants of a city's attractiveness.

A combination of necessary (flood protection) and desirable activities fosters public and also political acceptance of urban river revitalisation measures.

Implementation. Preferable, start revitalisation of a river or stream from the upper reaches downstream. Otherwise, the current emerging from a paved stretch and encountering the stronger coarseness of a renaturated stretch may develop strong erosive forces and require comprehensive pavements in the transition area. Upstream drainage conditions always determine the flood prevention measures in the territory considered for revitalisation.

The surveys of the project area must be thorough and qualified. Need to eliminate sources of pollution in the catchment area as a precondition for proper revitalisation and increase the self-cleaning capacity of water bodies. Ensure that construction is supervised with respect to ecological issues so that the goals are met.

Take a priority bio-engineering measures rather than technical solutions.

Scientific and educational compound of the river revitalization project and public relations activities. A prerequisite for a successful project should be a comprehensive study of the ecology of the river. Attracting educational institutions will help not only to collect the necessary information, but also increase the knowledge of schoolchildren and students about the features of the region. It is possible to provide an implementation public education programs and improve training in revitalisation principles that target different social groups.

A significant role is efforts to secure positive media coverage and public perceptions of the project by implementing an on-going information campaign for the project. Remember to use always the same logos and graphic design. It is very important to promote the project and its benefits by organizing events, celebrations, ground-breaking ceremonies, inaugurations, guided tours, leaflets, press relations, exhibitions, display boards, etc. Raise awareness of the manifold benefits of revitalisation project promotes successful implementation of it. So it is important to disseminate information about good and best revitalisation practices examples among decisionmakers and the general public.

Financing. Including solutions to water management tasks in the revitalisation project makes its funding and implementation more likely.

It is important to respond quickly to available funds is a frequent experience in public administrations, as payments from environmental impact mitigation regulation or other fees may suddenly become available or funds have to be spent before the fiscal year ends.

Endeavour to find adequate co-financing, because the municipal budget is characterised by fundamental restrictions in many places. Analyse opportunities for dividing the project into several stages that are realised step-by-step and financed from different sources. Obtain information on possible grants from various sources. Find institutions (sponsors) that are able to make a permanent contribution to the project, even if it is small (particularly during maintenance). Use impact mitigation regulation / impact mitigation fees to finance revitalisation projects. Explore possibilities for private funding (e.g. foundations, Private-Public-Partnerships, sharing costs with private developers).

Try to consider the costs as completely as possible in order to avoid miscalculation. Budget enough funding to allow for good planning and maintenance. A river revitalisation project can be sustainable only if the investment is well prepared during the planning phase and if future maintenance is assured. Try to reduce maintenance costs. Maintenance costs can get expensive and are often not taken into account at the start of a project. Factor in enough funding to cover unforeseen minor and major changes during the construction work. Calculate enough funding to provide adequate resources for public participation.

\section{Conclusions}

1. The successful implementation of the global goals of restoring the Earth's water objects in the context of sustainable development is impossible without solving the regional problems of local watercourses and reservoirs reviving. Awareness of riparian spaces role as ecological corridors and areas for social activities and also of the importance of the healthy functioning of the river network through the revitalisation of even minor watercourses leads to growth attention to this problem in an increasing number of countries. Ukraine, as an integral part of the world community, is striving to restore its water resources and revive rivers.

2. Current approaches to solving the problem of river revitalization have their differences in different countries. These differences are based on the purpose of using a watercourse. In European countries, the basis for the approach to river revitalization is their functioning as integral ecosystems. The result of this approach is an attempt to maximize the restoration of the river to it natural state, minimize the anthropogenic pressure, harmonize the relationship between people and nature. In Ukraine, today, the main focus of river restoration is on cleaning them from silt sediment. At the same time, the following goals are being pursued: of an economic nature - the restoration of river navigation; flood control measures; solving a number of environmental problems. However, the latter are often not prioritized and, as a result, the real tasks of restoring hydroecosystems are not fully resolved.

3 . Based on the analysis of participation experience in various river revitalization projects, the main approaches to solving this problem are presented and characterized: 1) Enhancing the ecological functionality of the watercourse as an ecosystem; 2) Providing flood protection; 3) Increasing the residential, cultural and recreational value; 4) Securing permanently sustainable use of watercourses and their river valleys. The main stages of the implementation of river revitalization projects, especially in urban areas, are presented, and ideas are proposed for a comprehensive consideration of emerging problems. 


\section{References}

1. Global sustainable development report 2019: The future is now - Science for achieving sustainable development (United Nations, New York, 2019)

2. European Parliament, Directive 2000/60/EC of the European Parliament and of the Council establishing a framework for the Community action in the field of water policy. Official Journal of the European Communities L327 (2000)

3. N. Hanley, R. Wright, B. Alvarez-Farizo, Journal of Environmental Management 78 (2), 183 (2006)

4. J. Jílková, R. Holländer, L. Kochmann, J. Slavík, L. Slavíková, Journal of Comparative Policy Analysis 12(3), 229 (2010)

5. V.K. Khilchevskiy, Hydrology, hydrochemistry and hydroecology 2(45), 6 (2017)

6. V.K. Khilchevskiy, M.P. Zabokritska, Revitalizatsiya richok urbanizovanikh teritoriy dosvid ta problemy (Rivers revitalisation of urban areas - experience and problems). Paper presented at the $7^{\text {th }}$ All-Ukrainian scientific conference "The problems of Hydrology, hydrochemistry and hydroecology", Kyiv, 13-14 November 2018.

7. M.P. Zabokritska, Hydrology, hydrochemistry and hydroecology 3 (42), 64 (2016)

8. K. Lange (ed.), Urban Rivers - vital spaces. Guide for urban river revitalisation (Mercur Druck, Leipzig, 2012)

9. I.M. Malakhov, T.M. Alokhina, A.O. Bobko, Metodologichny pitannya transphormatsiyi geologichnogo seredovishcha u hirnichovidoduvnikh regionakh (Methodological issues of transformation of geological environment in oremining regions). (DC Oktant Press, Kryvyi Rih, 2011).

10. V Krivom Roghe prodolzaetsa ochistka reky Saksahan (The cleaning of the Saksahan River continues in the Kryvyi Rih) (2012), https://1kr.ua/photogallery-202.html. Accessed 13 Aug 2012

11. J. Meyerhoff, A. Dehnhardt, European Environment 17(1), 18 (2007)

12. R. Hassan, R. Scholes, N. Ash, Ecosystems and human well-being. Current state and trends (Island Press, Washington, 2005)

13. B. Fisher, R. Turner, Biological Conservation 141(5), 1167 (2008)

14. R. Groot, M. Wilson, R. Boumans, Ecological economics 41(3), 393 (2002)

15. T.M. Alokhina, Ratsionalne prirodokoristuvannya $v$ kontexty stalogo rozvitku (Sustainable environmental management in the context of sustainable development). Paper presented at the international scientific conference "Sustainable development of an industry and society", Kryvyi Rih, 25-27 May 2016 